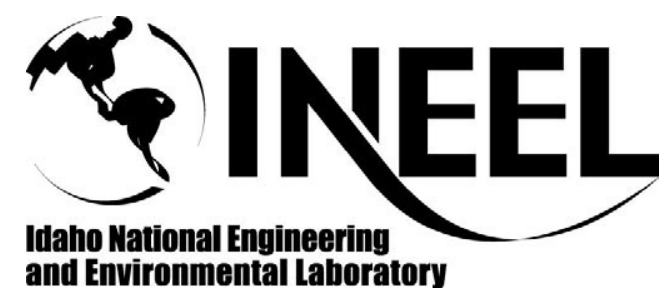

INEEL/CON-02-00289

PREPRINT

Key Differences In The Fabrication, Irradiation And High Temperature Accident Testing Of US and German TRISO-Coated Particle Fuel, And Their Implications On Fuel Performance

\author{
D. A. Petti \\ J. Buongiorno \\ J. T. Maki \\ R. R. Hobbins \\ G. K. Miller
}

April 22-24, 2002

HTR-T 2002

This is a preprint of a paper intended for publication in a journal or proceedings. Since changes may be made before publication, this preprint should not be cited or reproduced without permission of the author.

This document was prepared as an account of work sponsored by an agency of the United States Government. Neither the United States Government nor any agency thereof, or any of their employees, makes any warranty, expressed or implied, or assumes any legal liability or responsibility for any third party's use, or the results of such use, of any information, apparatus, product or process disclosed in this report, or represents that its use by such third party would not infringe privately owned rights. The views expressed in this paper are not necessarily those of the U.S. Government or the sponsoring agency. 


\title{
Key differences in the fabrication, irradiation and high temperature accident testing of US and German TRISO-coated particle fuel, and their implications on fuel performance
}

\author{
D.A. Petti*, J. Buongiorno, J.T. Maki, R.R. Hobbins, G.K. Miller \\ Idaho National Engineering and Environmental Laboratory, P.O. Box 1625, Idaho Falls, ID 83415-3860, USA
}

\begin{abstract}
Historically, the irradiation performance of TRISO-coated gas reactor particle fuel in Germany has been superior to that in the US. German fuel generally has displayed gas release values during irradiation three orders of magnitude lower than US fuel. Thus, we have critically examined the TRISO-coated fuel fabrication processes in the US and Germany and the associated irradiation database with a goal of understanding why the German fuel behaves acceptably, why the US fuel has not faired as well, and what process/production parameters impart the reliable performance to this fuel form. The postirradiation examination results are also reviewed to identify failure mechanisms that may be the cause of the poorer US irradiation performance. This comparison will help determine the roles that particle fuel process/product attributes and irradiation conditions (burnup, fast neutron fluence, temperature, degree of acceleration) have on the behavior of the fuel during irradiation and provide a more quantitative linkage between acceptable processing parameters, as-fabricated fuel properties and subsequent in-reactor performance. (C) 2003 Elsevier Science B.V. All rights reserved.
\end{abstract}

\section{Introduction}

High temperature gas reactor technology is achieving a renaissance around the world. Without a conventional containment, this technology relies on high quality production and performance of coated particle fuel. The behavior of this fuel over the past three decades has been mixed. The Germans have demonstrated high quality production of TRISO-coated fuel and excellent irradiation and safety test behavior under reactor relevant conditions. By contrast, for nominally the same fuel under very similar service conditions, the US fuel has been much less satisfactory. Our goal is to critically compare the German and
US fuel fabrication processes and the corresponding irradiation databases to identify the technical reasons for the differences in in-reactor behavior and to identify those specific fuel attributes and/or fabrication process conditions that impart superior in-reactor performance to TRISO-coated particle fuel.

\section{Fabrication processes}

A review of the fabrication processes used in Germany and the US to make coated particle fuel indicates that the scale of fuel fabrication and development efforts in the last 25 years were quite different (Petti et al., 2002). German fabrication of modern TRISO fuel was industrial/production scale incorporating improvements from fuel production for 
the German AVR reactor. Strict process control was used to adhere to a process specification that produced high quality fuel. Only $\sim 100$ defects were found in 3.3 million particles produced. By contrast, the US program, for post Fort St. Vrain fuel production, was a mixture of lab scale and larger scale fabrication with some fuel fabrication done by General Atomics and some done by Oak Ridge National Laboratory. Furthermore, different fuel and coating types, different fabrication process parameters, and different coaters and compact fabrication techniques were used in an attempt to produce high quality fuel. The result was an initial defect level that varied greatly and was much greater than that produced in Germany.

Table 1 compares each of the steps in the fabrication of German and US TRISO-coated fuel. The US fabrication is based on the fabrication of fuel for the New Production Reactor (NPR) program in the early 1990s. It is important to note that many of the steps used to make this fuel were unique to the program and are not considered part of the traditional US fabrication effort. Nevertheless, the NPR experience was used primarily because it was the last manufacturing campaign in the US and represents the most complete manufacturing pedigree and testing campaign of modern US TRISO fuel, albeit HEU, aimed at commercial scale deployment. Furthermore, because the US did not have a highly focused goal like the Germans, kernel and coating types varied, different coaters and coating conditions were used, all of which made selection of a US "reference" fabrication process for this comparison problematic.

Both German and US fuel fabrication processes consist of a number of similar steps. Kernels are made via a sol-gel process, followed by washing, drying, and calcining to produce $\mathrm{UO}_{2}$ kernels in Germany and UCO kernels in the US. The major difference consists of the addition of carbon black to the broth and a sintering step using $\mathrm{CO}$ in the US process to ensure adequate $\mathrm{C} / \mathrm{O}$ stoichiometry in the UCO kernel. The coating processes for the buffer are similar, based on chemical vapor deposition from a mixture of $\mathrm{Ar}$ and acetylene in a coater between 1250 and $1300^{\circ} \mathrm{C}$. A 5 - $\mu \mathrm{m}$ seal coat is produced in the US to seal the buffer; this step does not occur in the German process.

Major differences in the production of the TRISO coating are the coater design and the fact that all three layers are coated in a continuous manner in the
German process, whereas in the US process the fuel particles are unloaded after each coating layer to perform quality control (QC) measurements. The inner pyrocarbon layer in both cases is deposited from a mixture of acetylene, propylene, and argon. The temperature in the US process is somewhat lower than in German process and coating gas concentrations are different, resulting in a different coating rate, and producing a different microstructure for the IPyC. The impact of this difference in IPyC properties is discussed in more detail in Section 4. The SiC layer is deposited from a mixture of hydrogen and methyltrichlorosilane, at similar coating rates and active coating gas ratios, although the temperature for US coating is about $150^{\circ} \mathrm{C}$ higher than that used in the German process. The implication of this difference is also discussed in Section 4. The OPyC layer is coated in a manner similar to the IPyC layer. In the US NPR fuel, seal coats and protective pyrocarbon (PPyC) were added which are not standard in US fabrication. Neither is used in the German process.

The fuel pebble in Germany includes graphite powder and organic binders to produce a powder matrix that is used to overcoat the particles and to create the fuel pebble. In the US, a liquid matrix composed of petroleum pitch, graphite flour, and graphite shim mixed with additives is used to make the fuel compact. Both fuel forms are pressed and then carbonized at high temperature $\left(800-900^{\circ} \mathrm{C}\right) . \mathrm{HCl}$ is used to leach impurities from the US compact. Ultra high purity systems and feedstock are used in the manufacture of pebbles in Germany to ensure adequate control of impurities. Both fuel forms undergo a final heat treatment with the US compact heated at $1650^{\circ} \mathrm{C}$ in an Ar purge and the German pebble heated to $1950^{\circ} \mathrm{C}$ in vacuum. It appears that the major difference in as-manufactured fuel quality between German and US fuel, expressed as heavy metal contamination and $\mathrm{SiC}$ defects, arises from differences in fabrication of the fuel bodies (German pebbles versus US compacts). The reader is invited to consult Petti et al. (2002) for a detail review of the fabrication process for the US, German, Japanese, and Chinese TRISO-coated particle fuel.

Fig. 1 compares the beginning of life $\mathrm{Kr}-85 \mathrm{~m}$ release-to-birth ratio $(R / B)$ for German and US irradiations discussed earlier in this section. This measurement was selected as a metric of as-manufactured quality. The results show that German fuel had 
Table 1 (Continued)

\begin{tabular}{lll}
\hline & US NPR & German \\
\hline Coating process & Discontinuous & Continuous \\
Binders & Petroleum pitch & Phenol, hexamethylene-tetramine \\
Matrix state & Liquid & Powder \\
Overcoating $(\mu \mathrm{m})$ & Not applicable & 200 \\
Pre-pressing & Not applicable & $25^{\circ} \mathrm{C}, 30 \mathrm{MPa}$ \\
Pressing & $160^{\circ} \mathrm{C}, 6.9 \mathrm{MPa}$ & $25^{\circ} \mathrm{C}, 300-350 \mathrm{MPa}$ \\
Lathing & $\mathrm{N} / \mathrm{A}$ & Yes \\
Carbonization & $900^{\circ} \mathrm{C}$ in alumina powder and $\mathrm{N}_{2}$ & $800-900^{\circ} \mathrm{C}$ in inert gas \\
Leaching & $\mathrm{HCl}$ & Not applicable \\
Heat treatment & $1650^{\circ} \mathrm{C}$ in Ar & $1800-1950^{\circ} \mathrm{C}$ in vacuum \\
\hline
\end{tabular}

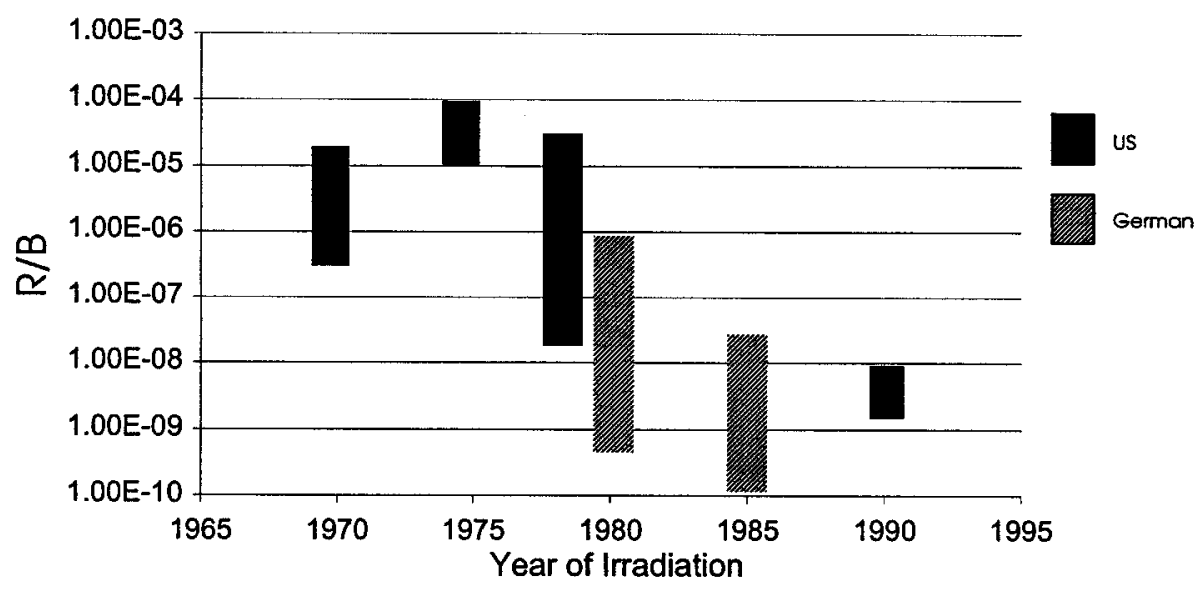

Fig. 1. Comparison of the beginning of life $\mathrm{Kr}-85 \mathrm{~m}$ release-to-birth ratio $(R / B)$ from German and US irradiations as an indicator of initial as-manufactured fuel quality.

consistently lower initial defects than the US fuel in the 1980 s and further that it improved over that time as was the case for fuel used in AVR; in fact the lowest ever $R / B$ measured in an in-reactor irradiation is from German fuel $\left(\sim 10^{-10}\right)$. The initial defect level in US fuel was much higher and showed great variability in the time from 1970 to 1980 . The level did not significantly change until the early 1990s when serious effects at reduction of initial contamination were undertaken in the fabrication campaign. Unfortunately, those very low levels of contamination were followed by in-reactor fuel failures at the percent level.

\section{Irradiation performance}

Numerous in-pile irradiation experiments have been conducted in both the US and Europe as part of the
US and German TRISO-coated particle fuel development efforts (Gontard and Nabielek, 1990; Petti et al., 2002). These irradiations were conducted at a variety of burnups, temperatures, and fluences. The rate of accumulation of burnup and fast fluence (i.e. the degree of acceleration) in the irradiation relative to that expected in the reactor may also be an important difference. For most of these fuels, the time to reach goal burnup and fast fluence is $\sim 1095$ days ( 3 years) in the reactor whereas in the irradiations the time to reach peak conditions was accelerated by factor of 2-10. A summary of salient features of the irradiations is found in Table 2.

Our detailed review indicates that the US and German irradiation programs were implemented quite differently with very different results. The German program's focus was on $\mathrm{UO}_{2}$-TRISO fuel for AVR and all future designs such as HTR Modul, whereas 
Table 1

Comparison of US and German TRISO-coated particle fuel fabrication

\begin{tabular}{|c|c|c|}
\hline & US NPR & German \\
\hline \multicolumn{3}{|l|}{ Kernel fabrication } \\
\hline Kernel material & HEU-UCO & LEU-UO ${ }_{2}$ \\
\hline Gel-precipitation & Internal & External \\
\hline Broth composition & $\begin{array}{l}\text { Aqueous solution of uranyl nitrate, } \\
\text { carbon-black, Tamol, urea, HMTA }\end{array}$ & $\begin{array}{l}\text { Aqueous solution of uranyl nitrate, polyvinyl } \\
\text { alcohol, and other non-specified additives }\end{array}$ \\
\hline Droplet formation & Vibrating nozzle & Vibrating nozzle \\
\hline Gelation medium & Trichloroethylene & Ammonia gas and ammonia solution \\
\hline Washing & Ammonia solution and clean water & Ammonia solution and isopropanol \\
\hline Drying & Ar at $60^{\circ} \mathrm{C}$ & Ar at $80^{\circ} \mathrm{C}$ \\
\hline Calcination & Ar at $350^{\circ} \mathrm{C}$ & Ar at $300^{\circ} \mathrm{C}$ \\
\hline Reduction & $\mathrm{H}_{2}$ at $1600^{\circ} \mathrm{C}$ & Not applicable \\
\hline Sintering & $\mathrm{CO}$ at $1800^{\circ} \mathrm{C}$ & $\mathrm{H}_{2}$ at $1600-1700^{\circ} \mathrm{C}$ \\
\hline \multicolumn{3}{|l|}{ Coating } \\
\hline Coating process & Discontinuous & Continuous \\
\hline \multicolumn{3}{|l|}{ Buffer } \\
\hline Gas composition & $\mathrm{Ar}-\mathrm{C}_{2} \mathrm{H}_{2}$ & $\mathrm{Ar}-\mathrm{C}_{2} \mathrm{H}_{2}$ \\
\hline Coating temperature $\left({ }^{\circ} \mathrm{C}\right)$ & 1300 & 1250 \\
\hline Coating rate $(\mu \mathrm{m} / \mathrm{min})$ & Not available & $6-10$ \\
\hline \multicolumn{3}{|l|}{ Seal } \\
\hline Gas composition & $\mathrm{Ar}-\mathrm{C}_{3} \mathrm{H}_{6}$ & Not applicable \\
\hline Coating temperature $\left({ }^{\circ} \mathrm{C}\right)$ & 1200 & Not applicable \\
\hline \multicolumn{3}{|l|}{ IPyC } \\
\hline Gas composition & $\mathrm{Ar}-\mathrm{C}_{2} \mathrm{H}_{2}-\mathrm{C}_{3} \mathrm{H}_{6}$ & $\mathrm{Ar}-\mathrm{C}_{2} \mathrm{H}_{2}-\mathrm{C}_{3} \mathrm{H}_{6}$ \\
\hline Coating temperature $\left({ }^{\circ} \mathrm{C}\right)$ & 1230 & 1300 \\
\hline Coating concentration/rate $(\mu \mathrm{m} / \mathrm{min})$ & Low $/<4$ & Higher/4-6 \\
\hline \multicolumn{3}{|l|}{$\mathrm{SiC}$} \\
\hline Gas composition & $\mathrm{H}_{2}-\mathrm{CH}_{3} \mathrm{SiCl}_{3}$ & $\mathrm{H}_{2}-\mathrm{CH}_{3} \mathrm{SiCl}_{3}$ \\
\hline Coating temperature $\left({ }^{\circ} \mathrm{C}\right)$ & 1650 & 1500 \\
\hline Coating rate $(\mu \mathrm{m} / \mathrm{min})$ & $0.2-0.4$ & 0.2 \\
\hline \multicolumn{3}{|l|}{ OPyC } \\
\hline Gas composition & $\mathrm{Ar}-\mathrm{C}_{2} \mathrm{H}_{2}-\mathrm{C}_{3} \mathrm{H}_{6}$ & $\mathrm{Ar}-\mathrm{C}_{2} \mathrm{H}_{2}-\mathrm{C}_{3} \mathrm{H}_{6}$ \\
\hline Coating temperature $\left({ }^{\circ} \mathrm{C}\right)$ & $>1300$ & 1300 \\
\hline Coating concentration $/$ rate $(\mu \mathrm{m} / \mathrm{min})$ & Low $/<4$ & Higher/4-6 \\
\hline \multicolumn{3}{|l|}{ Seal } \\
\hline Gas composition & $\mathrm{Ar}-\mathrm{C}_{3} \mathrm{H}_{6}$ & Not applicable \\
\hline Coating temperature $\left({ }^{\circ} \mathrm{C}\right)$ & 1200 & Not applicable \\
\hline \multicolumn{3}{|l|}{ PPyC } \\
\hline Gas composition & $\mathrm{Ar}-\mathrm{C}_{2} \mathrm{H}_{2}$ & Not applicable \\
\hline Coating temperature $\left({ }^{\circ} \mathrm{C}\right)$ & 1300 & Not applicable \\
\hline Coating rate $(\mu \mathrm{m} / \mathrm{min})$ & Not available & Not applicable \\
\hline \multicolumn{3}{|l|}{ Seal } \\
\hline Gas composition & $\mathrm{Ar}-\mathrm{C}_{3} \mathrm{H}_{6}$ & Not applicable \\
\hline Coating temperature $\left({ }^{\circ} \mathrm{C}\right)$ & 1200 & Not applicable \\
\hline \multicolumn{3}{|l|}{ Fuel element manufacture } \\
\hline Fuel element & Compact & Pebble \\
\hline Matrix materials & $\begin{array}{l}\text { Graphite flour, graphite shim, } \\
\text { octadecanol, polystyrene }\end{array}$ & Graphite powder \\
\hline
\end{tabular}




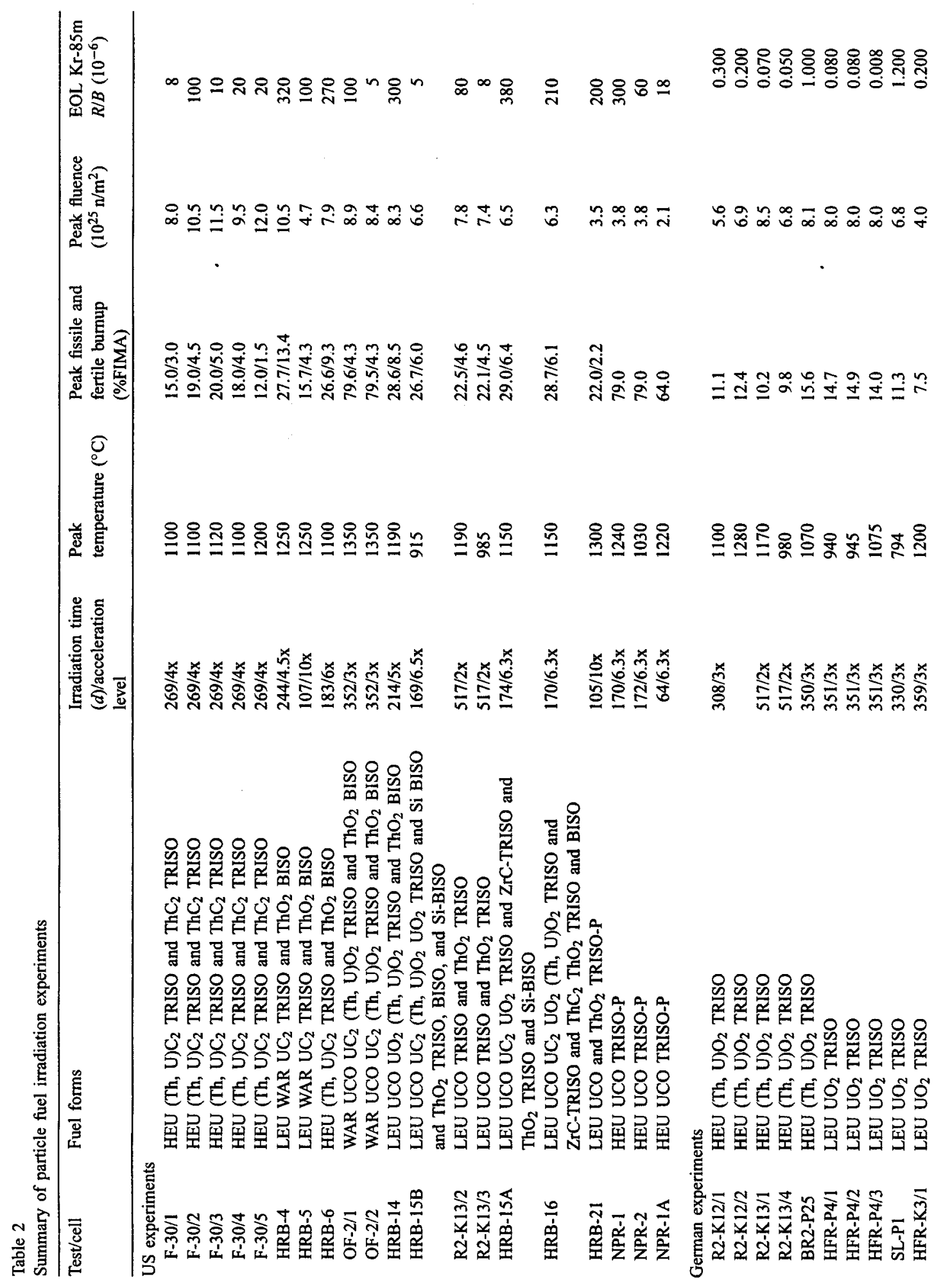




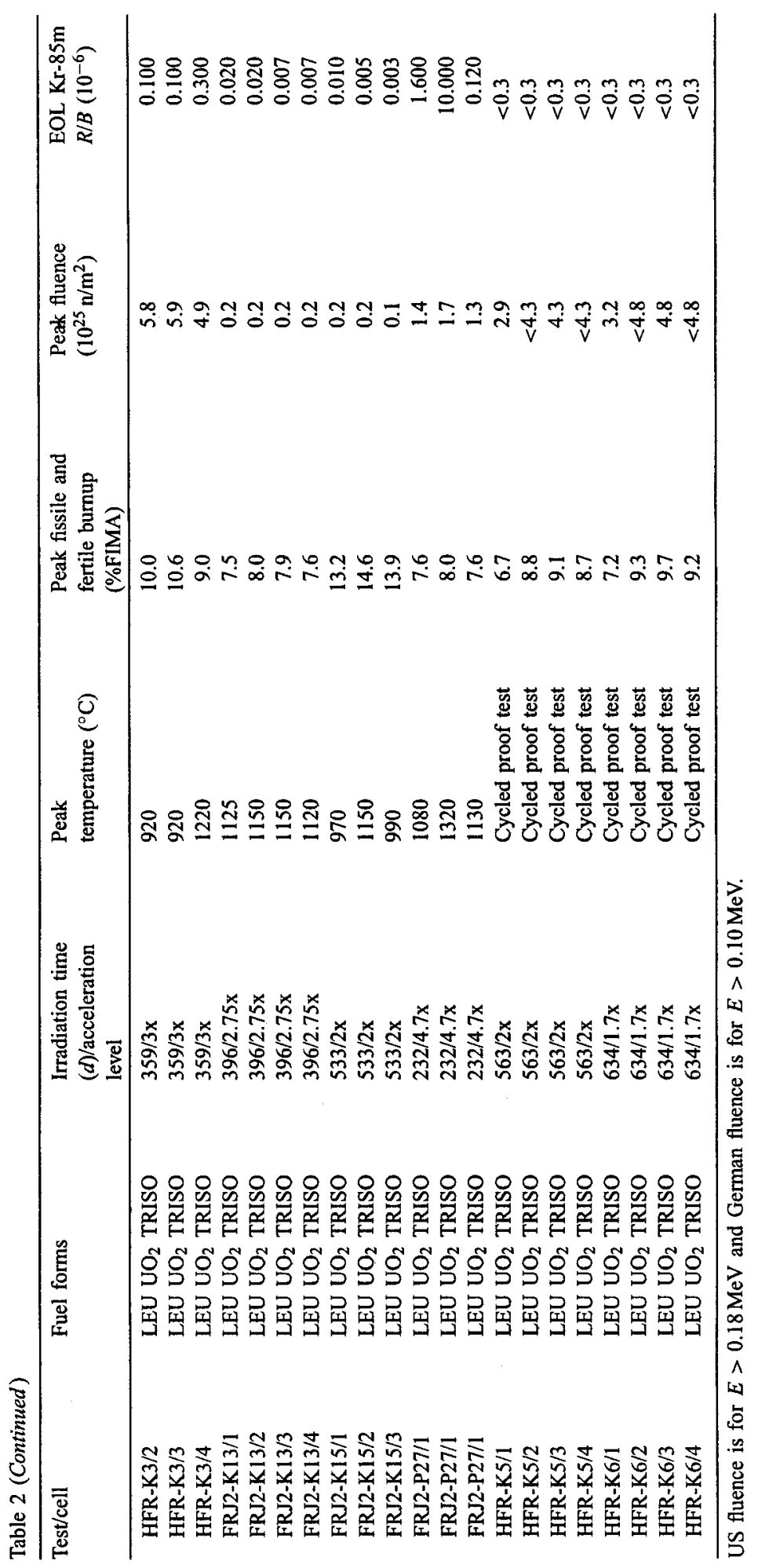




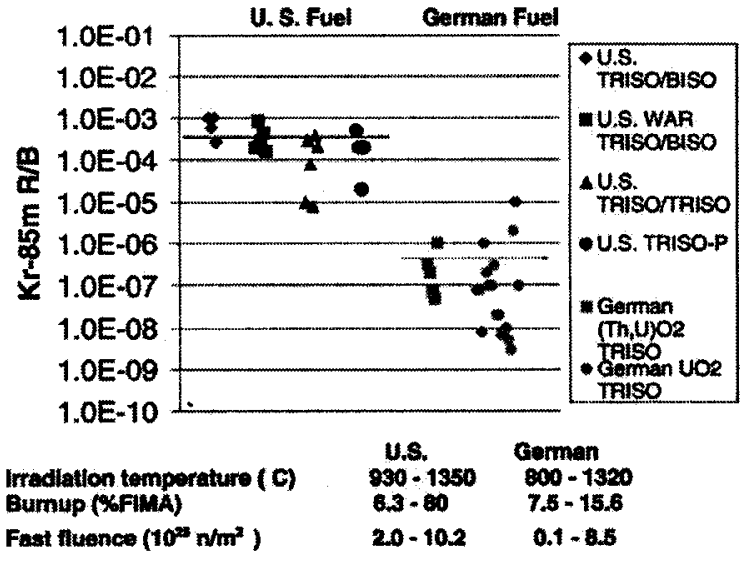

Fig. 2. Comparison of $\mathrm{Kr}-85 \mathrm{~m}$ release-to-birth ratio $(R / B)$ from historic German and US irradiations.

the US program examined many different variants (different coatings, different kernels). Fig. 2 plots the maximum $\mathrm{Kr}-85 \mathrm{~m}$ release-to-birth $(R / B)$ ratio measured in US and German irradiations. (In most cases, the maximum $R / B$ ratio was measured at the end-oflife, however in some irradiations, the final portion of the experiments was conducted at a lower temperature, which caused the $R / B$ at the end-of-life to decrease.) The on-line fission gas release-to-birth ratios $(R / B)$ indicate that German fuel exhibits about a factor of 1000 less fission gas release under irradiation than US fuel over a broad range of conditions (temperature, burnup, fluence). Plots of the end-of-life $\mathrm{Kr}-85 \mathrm{~m}$ gas release versus temperature, burnup, and fast fluence in Fig. 3 show no definitive trend. However, it is important to note that the German irradiations were generally performed at $1100^{\circ} \mathrm{C}$ whereas the US irradiation temperatures were usually higher, reflecting the higher maximum operating temperature in US prismatic designs.

Furthermore, the results from the postirradiation examinations confirm the more extensive and more reliable gas release data. German fuel is excellent. Out of $\sim 380,000$ LEU UO 2 TRISO and $\sim 80,000$ HEU (Th, $\mathrm{U} \mathrm{O}_{2}$ TRISO particles tested there were no in-pile failures and only a few "damaged" particles due to experimental anomalies. Gas release was attributed only to as-manufactured defects and heavy metal contamination. By contrast, as indicated in Fig. 4 during postirradiation examination of US fuel, percent level failures of individual layers of the TRISO coating were observed. (The values in the figure represent the maximum observed layer failure across all fuel batches in the experiment. The lack of a bar in the figure in most cases signifies that no data were tabulated on failure of that layer. In rare instances, no failure was observed.)

\section{Impact on in-reactor performance}

A comparison of the microstructures of the layers of the TRISO coatings in German and US fuel and a

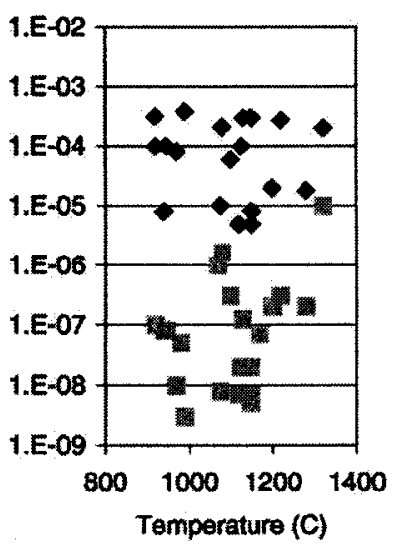

- US German

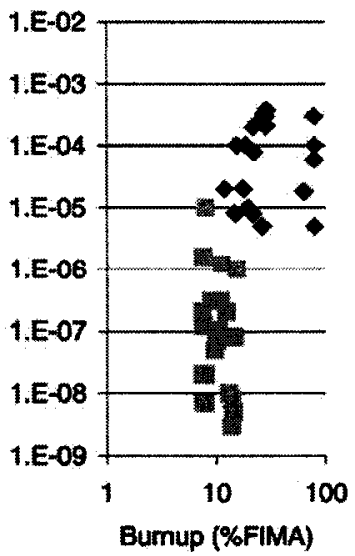

US German

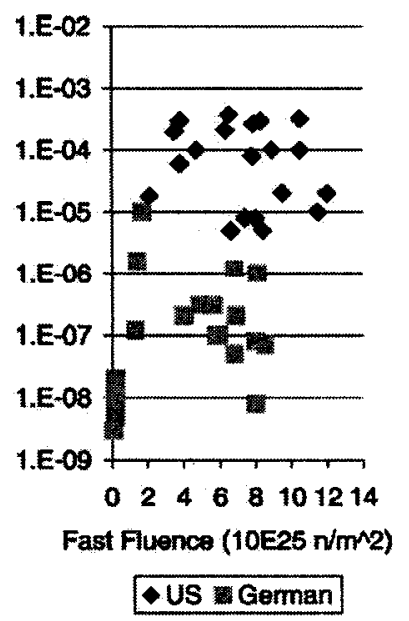

Fig. 3. Comparisons of the end-of-life $\mathrm{Kr}-85 \mathrm{~m}$ gas release from German and US fuel irradiations as functions of temperature, burnup, and fast fluence. 


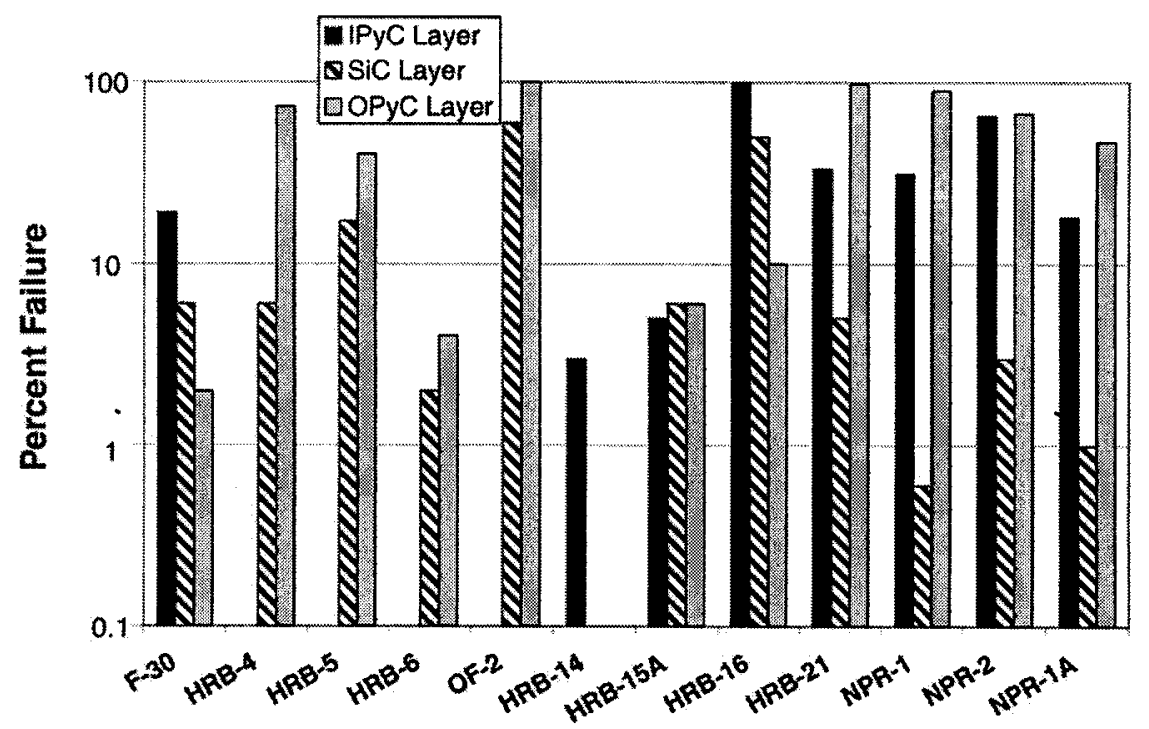

Fig. 4. Failures observed during postirradiation examination of US coated particle fuel over the past 25 years.

detailed review of the fabrication processes has revealed many differences. There are three specific technical differences in the coating layers produced by the respective fabrication processes that have important impacts in terms of performance under irradiation and accident conditions: pyrocarbon anisotropy and density, IPyC/SiC interface structure, and $\mathrm{SiC}$ microstructure.

\subsection{Pyrocarbon anisotropy and density}

The density and anisotropy of PyC is determined by the conditions in the coater (Martin, 2000). German pyrocarbon is deposited at a higher coating gas concentration, which in turn results in a higher coating rate $(\sim 4-6 \mu \mathrm{m} / \mathrm{min})$. This pyrocarbon is very isotropic and thus survives irradiation quite well. However, the conditions appear to lead to somewhat greater surface porosity than in US pyrocarbon. US pyrocarbon has been coated under a variety of conditions. In many cases it was coated at very low coating gas concentrations, which results in a lower coating rate $(1-4 \mu \mathrm{m} / \mathrm{min})$, and leads not only to a very dense and impermeable IPyC layer, which is important to preventing attack of the kernel by the coating gas during deposition of the $\mathrm{SiC}$ layer, but also to excessive anisotropy that can cause cracking of the PyC under irradiation. Postirradiation examination of many of the US capsules indicate shrinkage cracks in the inner pyrocarbon layer which has been shown (Baldwin et al., 1993; Miller et al., 2001; Maki et al., 2002) to lead to stress concentrations in the $\mathrm{SiC}$ layer and subsequent failure of the $\mathrm{SiC}$ layer. Photomicrographs of such irradiation-induced shrinkage cracks in the F-30 and NPR-1 irradiations are shown in Fig. 5. This review has also indicated that anisotropy measurements on PyC, especially by optical methods, fail to adequately correlate processing parameters to $\mathrm{PyC}$ isotropy, and furthermore are very unreliable as a predictor of in-reactor PyC failure. More reliable methods of anisotropy characterization are needed to ensure a link between acceptable coating processing parameters and satisfactory PyC in-reactor behavior.

\subsection{Nature of the IPyC/SiC interface}

Differences in the microstructure and surface porosity between the German and US IPyC lead to differences in the nature of the bond that exist between the layers. Photomicrographs of the $\mathrm{IPyC} / \mathrm{SiC}$ interface in German and US fuel are shown in Fig. 6. This figure shows that the interface in German fuel is more tightly bonded because $\mathrm{SiC}$ is deposited into $\mathrm{PyC}$, which has apparently greater surface porosity. For the US fuel, the denser less porous surface of the IPyC results in a smoother, less strong bond. The TRISO 

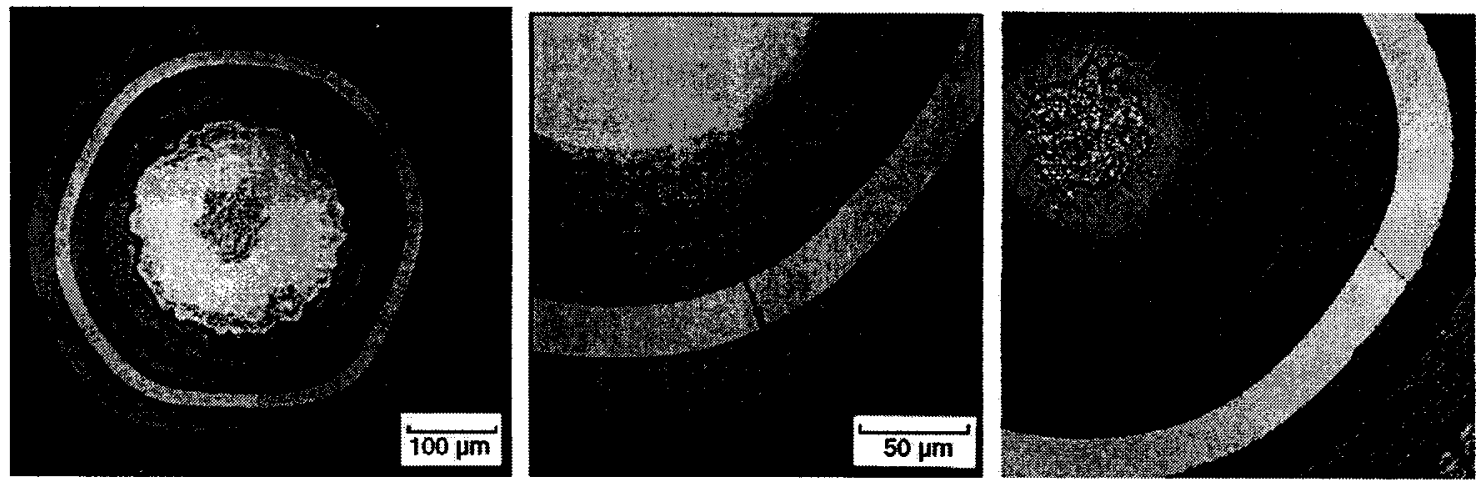

Fig. 5. Irradiation-induced cracking of inner PyC in F-30 irradiation (left and center photomicrographs) and NPR-1 irradiation (Maki et al., 2002; Scott and Harmon, 1975).

coating of German fuel never exhibits debonding under irradiation whereas $\mathrm{SiC}$ a review of the irradiation results indicates that the TRISO coating in US fuel debonds quite frequently. The debonding is believed to be related to the strength of the IPyC/SiC interface. The debonding as discussed in Section 5 can lead to stress intensification in the $\mathrm{SiC}$ layer that may cause failure.

\subsection{SiC microstructure}

The microstructures of German and US SiC are different as illustrated in Fig. 7. The German process results in small equiaxed grains whereas the US process produces larger columnar thru-wall grained $\mathrm{SiC}$. This difference in microstructure is believed to be primarily a function of temperature used during the $\mathrm{SiC}$ coating phase in the coaters, with the US coater producing
$\mathrm{SiC}$ at a higher temperature in some or all regions of the coater compared to the German process.

These differences could be important from a performance perspective because the smaller-grained German $\mathrm{SiC}$ with its higher tortuosity should in principle retain metallic fission products better than the large thru-wall columnar US $\mathrm{SiC}$ with more direct grain boundary pathways through the layer. Data from the HRB-15A experiment suggest that $\mathrm{Ag}$ release is a function of the microstructure of the SiC. Fig. 8 compares photomicrographs of two different types of $\mathrm{SiC}$ morphologies produced on US UCO fuel. The fuel was irradiated to $26 \%$ FIMA and a peak fluence of $5.4 \times$ $10^{25} \mathrm{n} / \mathrm{m}^{2}$ at a temperature of $\sim 1100^{\circ} \mathrm{C}$. Approximately $90 \%$ of the $\mathrm{Ag}$ was released from the large columnar grained $\mathrm{SiC}$ whereas only $\sim 30 \%$ was released in the smaller grained $\mathrm{SiC}$ microstructure. Fig. 9 is a photomontage of different $\mathrm{SiC}$ microstructures of
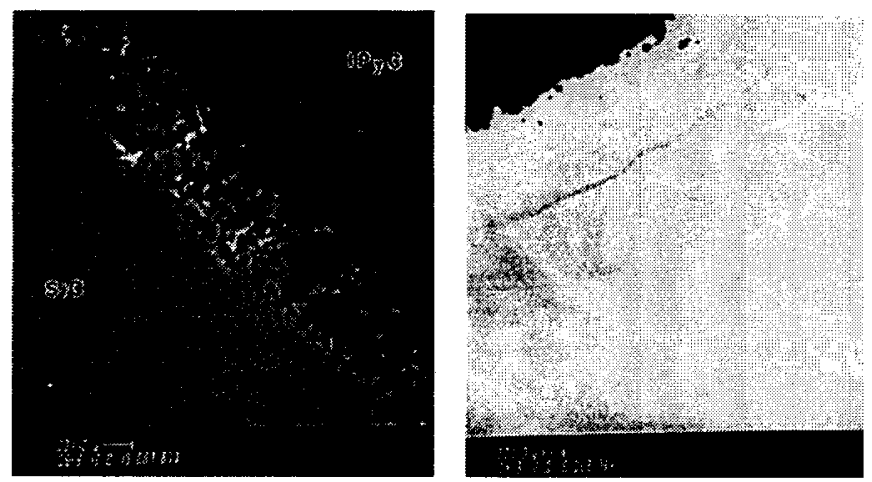

Fig. 6. Comparison of IPyC/SiC interface in German (left) and US (right) fuel (Saurwein and Schilling, 1993). The difference in contrast in the two pictures is associated with lighting techniques used in the examination. 

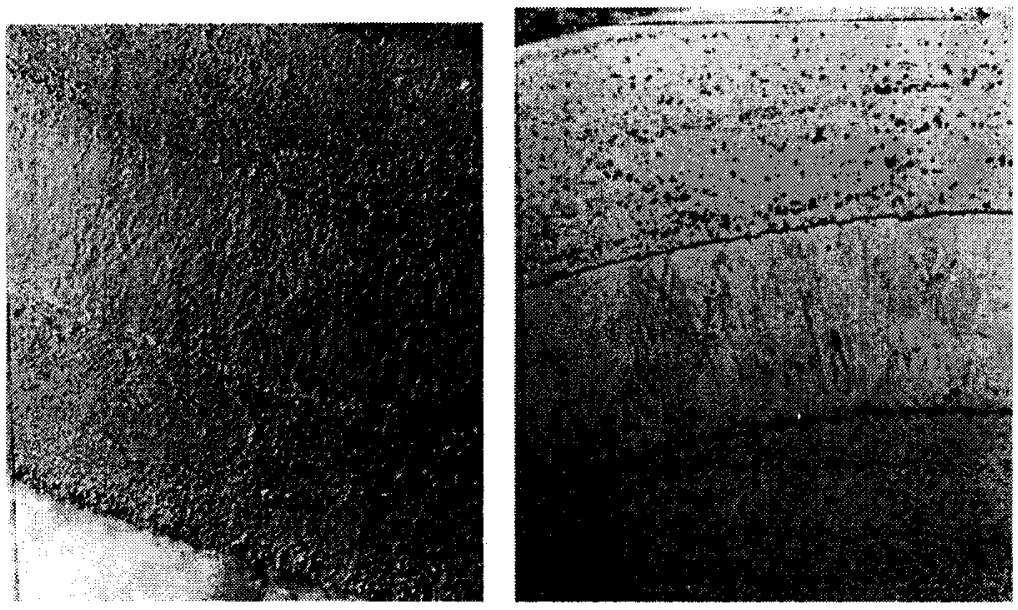

Fig. 7. Comparison of microstructure of German (left) and US (right) produced SiC (Saurwein and Schilling, 1993).

US coated particles with different kernels heated at $1500^{\circ} \mathrm{C}$ following irradiation. Releases of $\mathrm{Ag}$ and $\mathrm{Cs}$ were 100 and $24 \%$ from the $\mathrm{UO}_{2}$ particles with large columnar-grained $\mathrm{SiC}$. The weaker laminar $\mathrm{SiC}$ structure associated with the $\mathrm{UC}_{2}$ kernel also showed high $\mathrm{Ag}(82 \%)$ and $\mathrm{Cs}(12 \%)$ releases. The laminar $\mathrm{SiC}$ microstructures associated with UCO showed very little release of $\mathrm{Ag}$ and none of $\mathrm{Cs}$. The ability to make definitive statements about the role of $\mathrm{SiC}$ microstructure in fission product release from the coated particle is complicated by the fact that these data were obtained on fuels with different kernel types whose ability to retain metallic fission products may be different. In addition, the effect of grain size and morphology on Cs retention in SiC has been examined (Myers, 1989). The diffusivity of cesium through columnar $\mathrm{SiC}$ was given as an order of magnitude greater than through laminar SiC. While clearly not conclusive, grain structure appears to be important to fission product retention. Recently proposed experiments at MIT

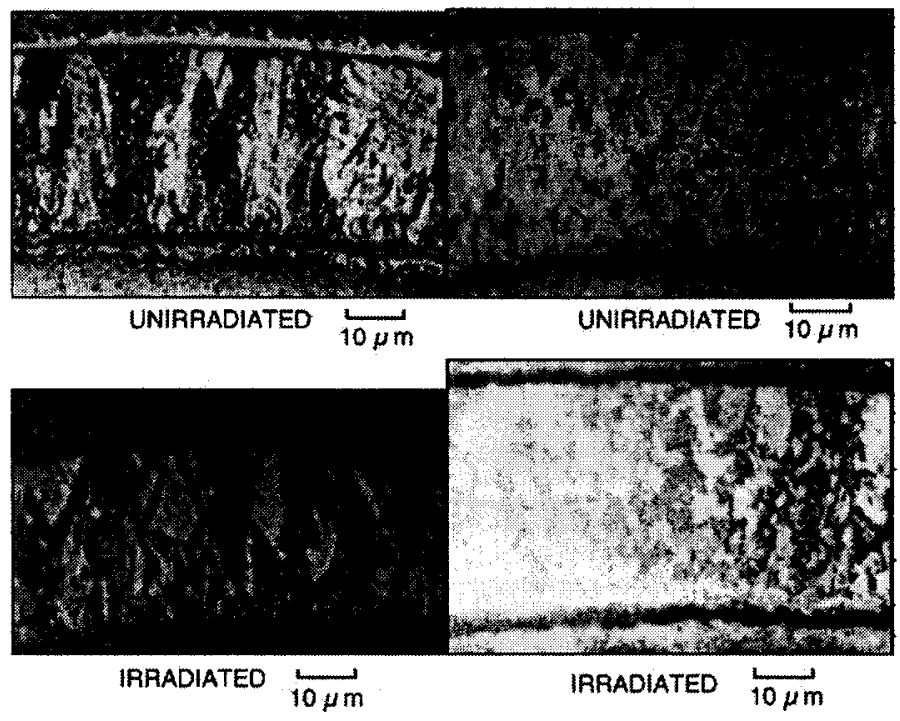

Fig. 8. Photomicrographs of large thru-wall columnar SiC grains and smaller SiC grains produced in UCO fuel irradiated in US HRB-15A. $\mathrm{Ag}$ release from these two fuels were different (Ketterer et al., 1984). 

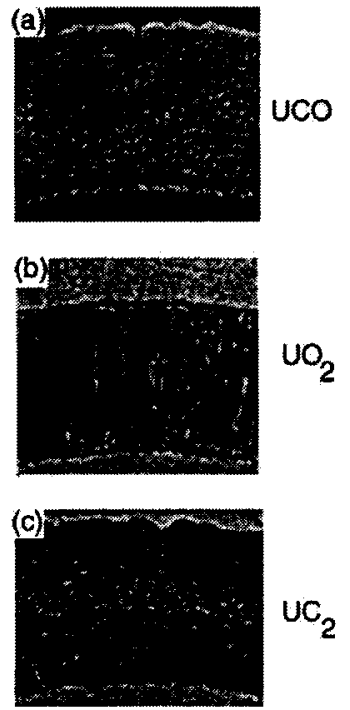

Fig. 9. Microstructures of different $\mathrm{SiC}$ layers on coated particles.

will attempt to answer this question more definitively (Petti et al., 2001).

\section{Failure mechanisms}

A review of the irradiation and safety testing of coated particle fuel reveals a number of potential failure mechanisms. These failure mechanisms are functions of temperature, burnup, fluence, and temperature gradient across the particle. Mechanisms that may result in particle failure, which ultimately leads to fission product release, are:

- Pressure vessel failure caused by internal gas pressure.

- Pyrocarbon layer cracking and/or debonding due to irradiation-induced shrinkage which ultimately leads to the failure of the $\mathrm{SiC}$ layer.

- Fuel kernel migration (amoeba effect), which leads to interactions with the coating layers.

- Fission product/coating layer chemical interactions.

- Matrix/OPyC interaction.

- As-manufactured defects produced during fabrication of fuel particles or during pressing of fuel compacts/spheres.

- Thermal decomposition of the $\mathrm{SiC}$ layer at very high temperatures.

- Enhanced SiC permeability and/or SiC degradation.
In this section, these mechanisms and the variables that control them are briefly described.

\subsection{Pressure vessel failure}

Under irradiation, coated particle fuel is subjected to a number of forces that put stress on the TRISO coating. One of the earliest recognized mechanisms is overpressure due to gas generation under irradiation. During irradiation, fission gases are released from the kernel to the porous buffer layer. The pressure that is generated exerts tensile forces on the IPyC and $\mathrm{SiC}$ layer of the particle. In addition to fission gas, in coated particle fuel with $\mathrm{UO}_{2}$ kernels, there is excess oxygen released during fission. (The rare earth and other fission products tie up about 1.6 atoms of oxygen per fission, leaving an excess of 0.4 atoms.) This excess oxygen will react with the buffer to form $\mathrm{CO}$ gas. Both the fission gas and $\mathrm{CO}$ production are functions primarily of burnup and temperature. In UCO fuels, $\mathrm{CO}$ is not produced provided sufficient uranium carbide is added to the kernel to ensure that there is no excess oxygen available from fission to react with the buffer layer over the burnup life of the fuel. The key variables that affect this mechanism are burnup and temperature. Fluence does not significantly affect these processes. Particles are generally sized with a large enough buffer to ensure that nominal particles do not fail by overpressure. Particle failure is postulated to occur in the event that during the coating process, particles are coated with an insufficient or missing buffer layer (i.e. insufficient void volume to accommodate the gases). Thus, fabrication specifications limit the number of particles produced with thin or missing buffer layers and impose limits on the statistical variation in kernel diameter and buffer thickness. Photomicrographs displaying overpressure failure in $\mathrm{ThO}_{2}, \mathrm{UO}_{2}$, and $\mathrm{UC}_{2}$ fuel are shown in Fig. 10. No indications of pressure vessel failure was observed in the German irradiations. This is a much analyzed but seldom seen failure mechanism.

\subsection{Irradiation-induced IPyC cracking and debonding}

Under irradiation, PyC shrinks in both the radial and tangential direction. At modest fluences $(\sim 2 \times$ $10^{25} \mathrm{n} / \mathrm{m}^{2}$ ) depending on the density, temperature and 

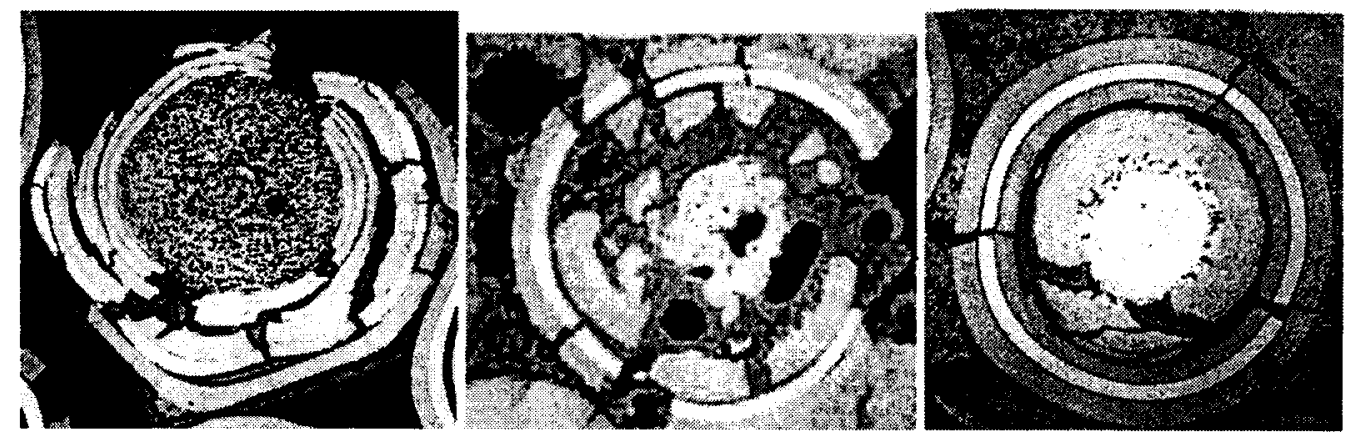

Fig. 10. Pressure vessel failure in a fertile fuel particle from HRB-14, a UO $\mathrm{U}_{2}$ particle from HRB-8 and a UC 2 particle from P13T.

anisotropy of the material, it begins to swell in the radial direction and continues to shrink in the tangential direction. This behavior puts the PyC layers into tension in the tangential direction. At longer irradiation times, irradiation-induced creep works to relieve the tensile stress in the PyC layer. If the $\mathrm{PyC}$ is strongly attached to the $\mathrm{SiC}$ layer, the PyC shrinkage provides a strong compressive stress in the $\mathrm{SiC}$ layer that offsets the tensile stresses generated by gas production. In fact, the particles are designed such that in intact particles, the $\mathrm{SiC}$ layer remains in compression throughout the irradiation.

The shrinkage, swelling, and creep behavior of the pyrocarbons is quite complex. Detailed stress calculations are used to model the evolution of stress and strain in all layers of the TRISO coating. In many of the US irradiations reviewed in Section 2, including the most recent from the DOE NPR Program, the shrinkage was much larger than anticipated and led to tangential stresses in the PyC high enough to cause cracking in the layer. These cracks led to stress concentrations in the $\mathrm{SiC}$ layer high enough to cause failure of that layer (Miller et al., 2001; Leikind et al., 1993). A plot of the tangential stress in the SiC layer of a TRISO-coated particle with an initially cracked IPyC is shown in Fig. 11. Photomicrographs of such shrinkage cracks found in the F-30 irradiation used to qualify fuel for Fort St. Vrain and the NPR irradiations are shown in Fig. 5. Postirradiation examination of German fuel did not reveal any shrinkage cracks in the IPyC layer as has been observed in US irradiations. Thus, the experimental evidence to date suggests
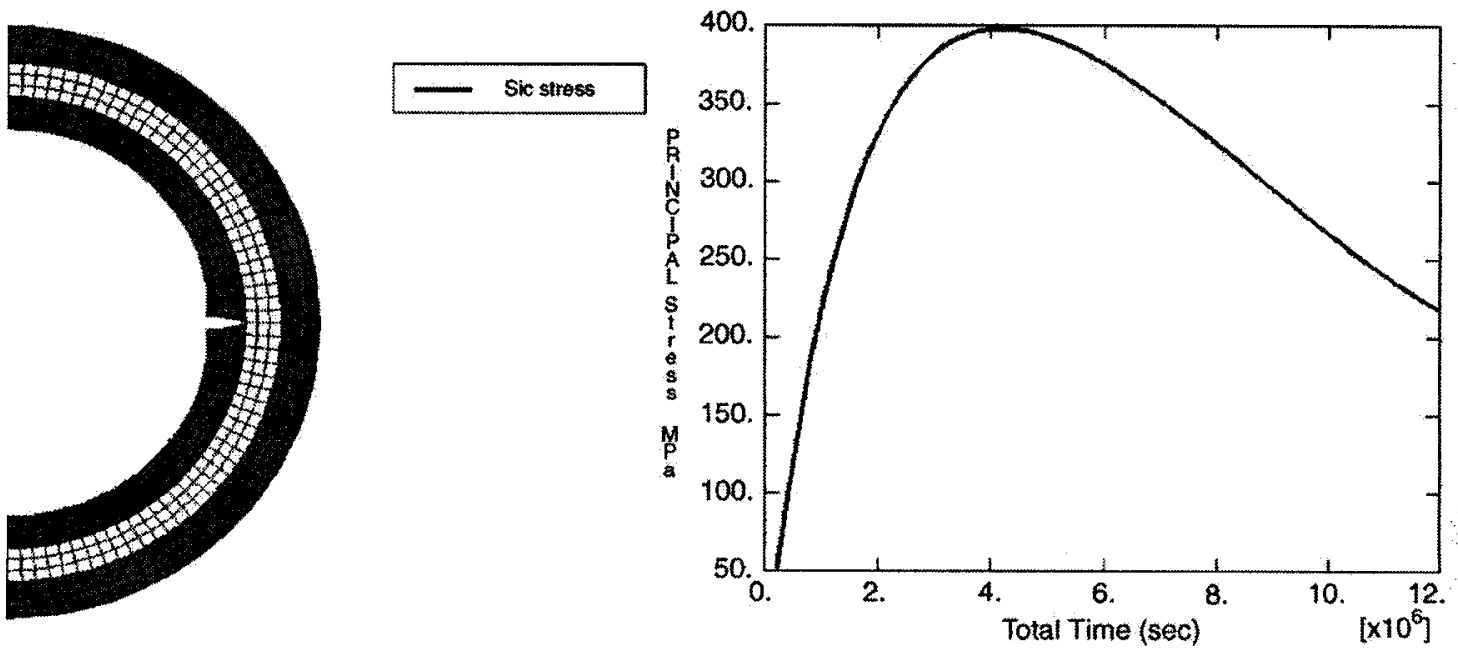

Fig. 11. Stress history in the SiC of a TRISO particle with cracked IPyC. 
that this mechanism is most likely not important for very isotropic PyC. This is by far the most common fuel failure mechanism observed in GA fuel. As discussed earlier this failure mechanism has been attributed to high anisotropy in the PyC layer resulting from deposition of the layer at too low of a coating gas concentration, and thus coating rate during manufacture of the fuel.

In addition to irradiation-induced shrinkage, debonding at the IPyC/SiC interface has been observed in many US irradiations. As discussed in Section 3, this debonding is believed to be related to the nature of the IPyC/SiC interface. Weakly bonded coating layers as in US fuel can partially detach because of the tensile stresses generated by the PyC shrinkage under irradiation. A particle for which partial debonding of the IPyC from the SiC has occurred can develop relatively large tensile stresses in the $\mathrm{SiC}$ (although significantly smaller than in the case of a cracked IPyC). The stress history for an initially partially debonded fuel particle is illustrated in Fig. 12. Tensile stresses occur at the point of IPyC/SiC contact as the IPyC shrinks under irradiation. Irradiation-induced creep relieves the stress at longer times. When these stresses are used in concert with Weibull statistics to calculate the $\mathrm{SiC}$ failure probability, it is found that the $\mathrm{SiC}$ fails at a low, but not insignificant, rate.

\subsection{Kernel migration}

Kernel migration is defined simply as movement of the kernel in the coated particle toward the TRISO coating. If the migration is excessive, the kernel will penetrate the TRISO coating leading to failure of the particle. Kernel migration, also known as the amoeba effect, is actually a misnomer. Kernel migration is associated with carbon transport in the particle in the presence of a temperature gradient. In the fuel kernel equilibrium is established among $\mathrm{C}, \mathrm{UO}_{2}$, and $\mathrm{CO}$. When there is a thermal gradient across the particle, the equilibrium is different on each side of the particle. The different equilibrium conditions lead to mass transport of carbon down the temperature gradient. This movement of carbon appears in photomicrographs of fuel as a movement of the kernel up the temperature gradient and hence the name kernel migration as shown in Fig. 13. This phenomenon is strongly dependent on the temperature and temperature gradient in the fuel with secondary dependence on burnup. In prismatic cores with $\mathrm{UO}_{2}$ fuel, where power densities in the particles are greater, the potential for kernel migration is greater. In pebble bed cores, the power densities and hence the thermal gradients are much smaller. Kernel migration was observed in a number of US irradiations (HRB-4, OF-2, HRB-14, HRB-16),
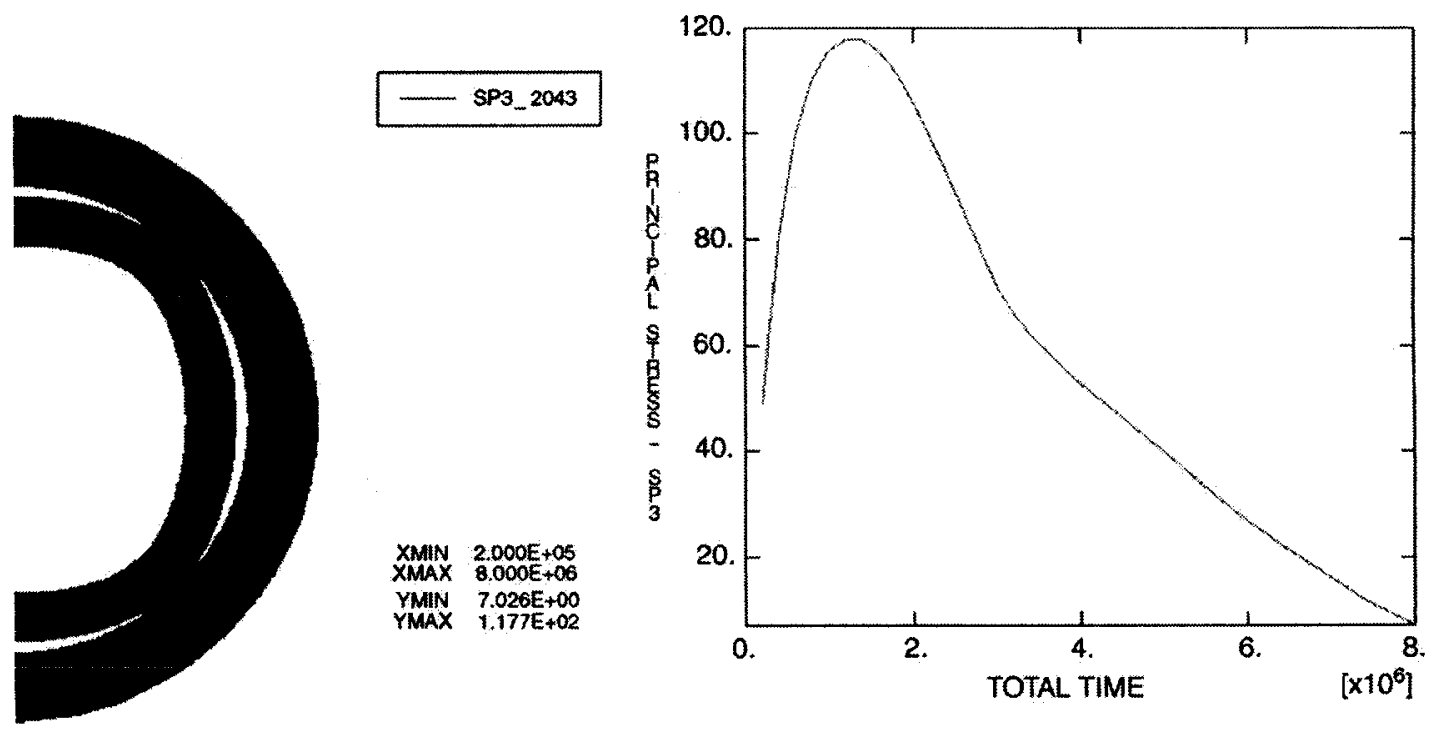

Fig. 12. Stress time history for the $\mathrm{SiC}$ layer near a partially debonded area. 


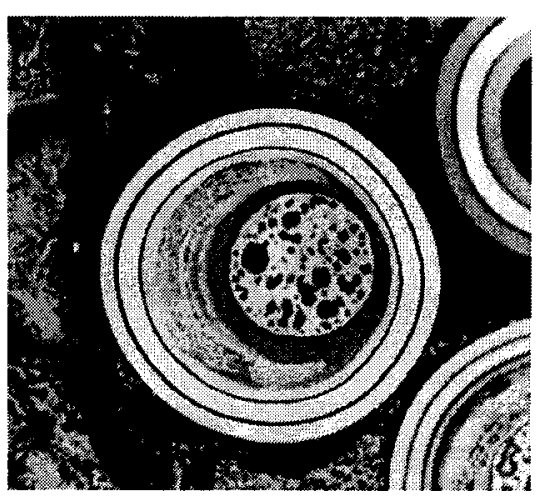

Fig. 13. Photomicrograph of kernel migration.

but has not been observed in German irradiation experiments or in AVR and THTR operation due to the low power densities and the lack of a sufficiently steep thermal gradient. For prismatic cores, this phenomenon prompted the US to change their kernel design from $\mathrm{UO}_{2}$ to $\mathrm{UCO}$, an oxycarbide kernel, in which no $\mathrm{CO}$ is produced and thus the equilibrium and carbon transport phenomena mentioned before are not expected to occur. In the most recent irradiation experiments with US, UCO fuel with a proper $\mathrm{C} / \mathrm{O}$ ratio kernel migration has not observed. In the design of irradiation experiments, it is important to limit the thermal gradient across the fuel specimen or power per particle to values that are typical of those in the reactor application to ensure that no false positives are observed.

\subsection{Fission product/coating layer chemical interactions}

Past irradiation experiments indicate that fission products can be transported from the kernel to the inner surface of the SiC where they interact and can damage and potentially fail the $\mathrm{SiC}$ layer. In older uranium carbide kernels rare earth fission product migration was of concern. In $\mathrm{UO}_{2}$ kernels, palladium is very important as are some other noble metal fission products. In UCO kernels, the oxycarbide form of the kernel generally ties up all fission products with the exception of the metals (e.g. Ag, Cs, Pd) as either carbides or oxides, which tend to limit their mobility in the UCO system. However, Pd transport has still been observed in UCO coated particle fuel. In addi- tion, although not a failure mechanism, the migration of silver in both $\mathrm{UO}_{2}$ and UCO has been observed. The silver can migrate through apparently intact particles and be released into the reactor coolant system where it will deposit on cold surfaces. For direct cycle gas reactors, this may be in the turbine, which has important maintenance (worker dose) implications. Studies have been conducted to understand the mechanism for the $\mathrm{Ag}$ migration through $\mathrm{SiC}$ and $\mathrm{Pd}$ attack of the $\mathrm{SiC}$. The migration of the fission products is thought to be a function of temperature and burnup as well as temperature gradient. Although a complete understanding of the phenomena is not available, the role of temperature gradient is recognized as being critical. The degree of fission product attack is generally correlated with the temperature gradient in the fuel. Thus, these fission product attack mechanisms are expected to play a more important role in prismatic reactors where power densities in the particle are larger than corresponding particles in a pebble bed reactor. A representative photomicrograph of this attack in US fuel is shown in Fig. 14. Chemical reactions between fission products and $\mathrm{SiC}$ layers have not been observed in German fuel at the conclusion of the irradiation experiments. However, during high temperature safety tests, palladium was identified as the primary fission product causing $\mathrm{SiC}$ degradation.

Also of note here is the fact that the enrichment of the fuel is important in defining the magnitude of the $\mathrm{Ag}$ and $\mathrm{Pd}$ problem. The yields of $\mathrm{Ag}$ and $\mathrm{Pd}$ are 25-50 times greater for Pu than for U. Thus, in LEU fuels where at the end-of-life significant fission comes from $\mathrm{Pu}$, the concentration of $\mathrm{Ag}$ and $\mathrm{Pd}$ can be much

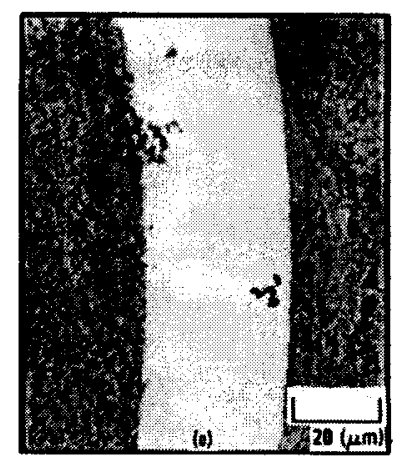

Fig. 14. Photomicrograph demonstrating fission product attack of the $\mathrm{SiC}$ layer. 
greater than in HEU fuel of similar burnups. As in the case of kernel migration, it is important to limit the thermal gradient or power per particle in the design of irradiation experiments to values that are typical of that in the reactor application to ensure that no false positives are observed.

\subsection{Matrix/OPyC interaction}

In many of the US irradiations, high levels of OPyC failure were observed (e.g: HRB-4, HRB-5, $\mathrm{OF}-2$ ) by cracking or debonding from the $\mathrm{SiC}$ layer. These failures were attributed to intrusion of the liquid carbonaceous matrix material in the $\mathrm{OPyC}$ during compact fabrication followed by shrinkage under irradiation. Specifications on the US matrix material and its injection were developed based on the irradiation experiments to limit this failure mechanism. In addition, in other US irradiations, irradiation-induced failure was observed, and attributed to a combination of unacceptable microporosity and anisotropy of the layer. Fuel fabrication specifications were developed in the US to limit this failure mechanism to $3 \%$ of all OPyC layers, a level considered acceptable based on fuel performance modeling at the time. No similar behavior was observed in German fuel because of the use of powder-based matrix material that does not tend to penetrate the $\mathrm{OPyC}$ and because of the higher isotropy of German PyC.

\subsection{As-manufactured defects}

In the absence of any of the above failure mechanisms, fission gas and metal release during irradiation is attributed to heavy metal contamination outside of the SiC layer and to initially defective particles. Initially defective particles can be the result of undetected defective particles that have not been removed during fabrication, attack of the particles during fabrication or irradiation by impurity metals (e.g. Fe), or particles that have failed as a result of the formation of the particles into a compact in a prismatic design or a pebble in the pebble bed design. The high level of as-manufactured defects in GA fuel is believed to be related to the introduction of impurities from the graphite furnace that attack the $\mathrm{SiC}$ layer during final heat treatment at $1700^{\circ} \mathrm{C}$ (McEachern, 2002). Numerous process improvements have been made to minimize these defects so that the fuel process specifi- cations can be met. For example, in German fuel, particles are tabled at numerous points during fabrication to remove out-of-round particles (after kernel, TRISOcoating deposition, and particle overcoating). Metal screens are no longer used in some fabrication lines to limit metal pickup during fabrication. During the NPR program, stringent control of key aspects of the process was used in prismatic fuel to limit heavy metal contamination. In pebble bed fuel, a soft overcoating is put on the particle after the OPyC layer to reduce out of roundness and to limit stresses induced by particle-to-particle contact during pebble manufacture. In prismatic fuel, recent process development work has been carried out to reduce particle stresses and limit introduction of impurities during compact formation.

During the three decades of German particle fuel production, the fraction of as-manufactured defects has continuously dropped to very low levels $\left(<1 \times 10^{-6}\right)$. This is evident by the low BOL $\mathrm{Kr}-85 \mathrm{~m}$ $R / B$ values (reaching a minimum value of $2 \times 10^{-10}$ in the FRJ2-K15 experiment) from each of the German experiments. Even at these low defect levels, as-manufactured defects were the most common source of particle abnormalities reported. In all, one fuel kernel was reported to be without coating in the FRJ2-P27 experiment and two kernels were reported to be without coating in the R2-K12 experiment. The particle failures cited in the HFR-P4 experiment were caused by contact with thermocouples and gas inlet tubes and thus, may be considered as failures due to fabrication of the test capsule and not as an intrinsic fault of the fuel.

\section{7. $\mathrm{SiC}$ thermal decomposition}

At very high temperatures $\left(>2000^{\circ} \mathrm{C}\right)$, thermodynamics and data from German high temperature heating tests show that the $\mathrm{SiC}$ layer undergoes thermal decomposition (Nabielek et al., 1989). This phenomenon is primarily a function of temperature and time and has not played a major role in fuel failure at lower accident temperatures $\left(1600-1800^{\circ} \mathrm{C}\right)$ where safety testing has been routinely performed.

\subsection{Enhanced SiC permeability and/or SiC degradation}

Although not formally a failure mechanism, there is some limited evidence (Schenk et al., 1990) that fast 
neutron fluence and/or burnup plays a role in the permeability or degradation of the $\mathrm{SiC}$ layer with respect to fission products during high temperature heating. Pebbles exposed to higher fluence $\left(4.6 \times 10^{25} \mathrm{n} / \mathrm{m}^{2}\right)$ and higher burnup (14\% FIMA) have exhibited a greater release of fission products (e.g. cesium) in heating tests than similar pebbles exposed to less severe conditions. This phenomenon could become more important as coated particle fuel is pushed to high burnup.

\section{Summary and conclusions}

Our review has concluded that there have historically been differences in the quality of US and German fuel as evidenced by the level of initial as-manufactured defects and the fuel performance results from many US and German irradiations. These differences in as-manufactured defects appear to be related to differences in the manufacture of the fuel body (pebble versus compact). The differences in irradiation performance have in part been traced to technical differences in the microstructures of the PyC and SiC layers in the TRISO coating and the bonding of those layers, which in turn are related to differences in the fabrication processes used in Germany and the US. In addition, part of the difference in the performance of these fuels has been attributed to the different philosophies and approaches used to implement the irradiation and testing programs in the two countries. German fabrication was industrial/production scale supporting the German AVR reactor, with a focus on $\mathrm{UO}_{2}$-TRISO fuel form. By contrast, the post Fort St. Vrain US program consisted of a mixture of lab scale and larger scale fabrication of many different variants of TRISO-coated particle fuel (different coatings, different kernels) produced with coaters of different designs under a variety of fabrication conditions. These fuel types were irradiated with apparently few lessons learned from one irradiation to the next and insufficient feedback to the fabrication process.

Detailed review of the US irradiation database indicates a number of different failure mechanisms of the individual layers of the TRISO coating contributed to the less than satisfactory US fuel performance. Failures of the coating layers were attributed to: (a) pressure vessel failure, (b) irradiation-induced IPyC cracking and/or debonding leading to cracking in the $\mathrm{SiC}$ layer, (c) kernel migration (amoeba effect), (d) fission product and/or impurity attack of the SiC layer, (e) matrix-OPyC interaction and irradiation-induced $\mathrm{OPyC}$ failure. The $\mathrm{PyC}$ related mechanisms are strongly related to the anisotropy and porosity in the coatings. The anisotropy has a strong influence on the shrinkage and swelling behavior of the PyC layers under irradiation. The porosity of the layer has an impact on the strength of the interfacial bond between the $\mathrm{SiC}$ and PyC. Fission product and impurity attack of the $\mathrm{SiC}$ and kernel migration are thermally driven phenomena that are strongly influenced by the burnup, temperature, and temperature gradient across the particle. The temperature gradient is a strong function of the power density in the fuel body. A US fuel compact has a higher packing fraction of particles (up to 50\%) than German pebbles $(\sim 10 \%)$. The US core design uses a higher fuel power density than the German core designs. This difference requires more severe testing conditions for the US fuel. Because of the potential fuel failure mechanisms associated with accelerated testing, German researchers recommend that the level of acceleration of any coated particle fuel irradiation be no greater than three times real time. The US irradiations were accelerated 3-10 times real time compared to the 2-3 times acceleration for most of the German irradiations. Thus, some of the phenomena that were observed in US irradiations may be attributed to the more demanding US core design and the accelerated nature of the irradiation. These differences in power density in each reactor drove the fuel designs. The Germans could use oxide fuel with little threat to fuel integrity by kernel migration or fission product attack because of the lower temperatures and temperature gradients in the fuel. By contrast, the US prismatic design with its high fuel operating temperature and power density (and resulting higher temperature gradient) resulted in the development of UCO kernels to minimize kernel migration and fission product mobility in the fuel. Had the US and German irradiations been conducted under similar conditions, the disparity in results may have been less but these differences certainly cannot entirely account for the factor of 1000 in measured performance. 


\section{Acknowledgements}

This work was supported through the INEEL Bechtel Corporate Funded R\&D (CFRD) Program under DOE Idaho Operations Office Contract DE-AC0799ID13727.

\section{References}

Baldwin, C.A., et al., 1993. The New Production Reactor Post Irradiation Examination Data Report for Capsules NPR-1, NPR-2 and NPR-1A. ORNL/M-2849.

Gontard, R., Nabielek, H., 1990. Performance Evaluation of Modern HTR TRISO Fuels. HTA-IB-05/90.

Ketterer, J.W., Kania, M.J., Bullock, R.E., Siman-tov, I.K., 1984. Capsule HRB-15A Postirradiation Examination Report. GA-A16758.

Leikind, B.J., et al., 1993. MHTGR TRISO-P Fuel Failure Evaluation Report. DOE-HTGR-903990.

Maki, J.T., et al., 2002. NP-MHTGR Fuel Development Program Results. INEEL/EXT-2002-1268.

Martin, D., 2000. Irradiation Damage in Graphite due to Fast Neutrons in Fission and Fusion Systems. IAEA-TECDOC-1154.
McEachern, D., 2002. General Atomics. Personal communication. Miller, G.K., Petti, D.A., Varacalle, D.J., Maki, J.T., 2001. Consideration of the effects on fuel particle behavior from shrinkage cracks in the inner pyrocarbon layer. J. Nucl. Mater. 295, 205-212.

Myers, B.F., 1989. Selective Aspects of Transport in SiC. Presentation to Experts Meeting on MHTGR-HTR Fuel Performance under Accident Conditions.

Nabielek, H., et al., 1989. The performance of high temperature reactor fuel particles at extreme temperatures. Nucl. Technol. $84,62$.

Petti, D.A., et al., 2001. Development of Improved Models and Designs of Coated-Particle Gas Reactor Fuels. International Nuclear Energy Research Initiative (INERI) Proposal for Collaborative Work with the French CEA

Petti, D.A., et al., 2002. Key Differences in the Fabrication, Irradiation and Safety Testing of US and German TRISOCoated Particle Fuel and Their Implications on Fuel Performance. INEEL/EXT-02-00300.

Saurwein, J., Schilling, L., 1993. Final Report-Testing of As-Manufactured NPR-PTF, German and U.S. Historical Fuel. General Atomics, No. 910647.

Schenk, W., Pott, G., Nabielek, H., 1990. Fuel accident performance testing for small HTRs. J. Nucl. Mater. 175, 19-30.

Scott, C.B., Harmon, D.P., 1975. Postirradiation Examination of Capsule F-30. GA-A13208. 